\title{
HUBUNGAN ANTARA KEMAMPUAN MANAJERIAL DAN PENGAWASAN DENGAN PRODUKTIVITAS KEPALA KOMPETENSI KEAHLIAN DI SMK NEGERI DKI JAKARTA
}

\begin{abstract}
Suharto*
Abstract: This Research is made to determine (1) the relationship between managerial skills with Head of Competence Skills productivity (2) the relationship of control activity to the Head of Competence Skills productivity (3) the relationship between managerial and control skills along with the Head of Competence Skills productivity. The research methodology that has been used was correlation approach survey. In this study, 145 Head of Skill Competency in selected SMK have been used as a sample by using simple random sampling techniques (simple random sampling). This research conducted in Jakarta area. Based on the description to hypothesis test, the research findings can be outlined as followed: (1) there is a positive relationship between managerial skills with the productivityof the Head of Competence Skills (2) there is a control relationship with the productivity of Head Competency Skills (3) there is a positive relationship between managerial ability andcontrol alongwith the Head of Competence Skills productivity. The implication of this study is an attempt of improving the productivity of the Head of Skill Competency that can be done through improved managerial and controlskills.
\end{abstract}

Keywords : managerial ability, control, and productivity

\section{PENDAHULUAN}

Kompetensi keahlian secara operasional merupakan institusi terdepan (ujung tombak) dari pendidikan SMK sehingga perannya sangat menentukan keberhasilan pendidikan SMK. Kompetensi keahlian inilah yang menjadi ciri khas dan identitas bagi siswa selama belajar di SMK. Setelah siswa dinyatakan lulus ijasahnya pun juga tertulis penguasaaan kompetensi sesuai dengan kompetensi keahlian yang ditempuh selama belajar di SMK. Manajemen pada Sekolah Menengah Kejuruan (SMK) dipimpin oleh seorang kepala sekolah yang dibantu sedikitnya empat wakil kepala sekolah. Pada tingkat kompetensi keahlian SMK dipimpin oleh seorang kepala kompetensi keahlian. kepala kompetensi keahlian sering disebut juga sebagai kepala sekolah kecil, yaitu kepala sekolah di tingkat kompetensi keahlian. Kepala kompetensi keahlian/ kepala program studi menjalankan tugas pokok dan fungsi membantu kepala sekolah dalam pengelolaan dan penyelenggaraan pembelajaran praktik dan pengelolaan bengkel sesuai dengan mekanisme dan prosedur masing-masing kompetensi keahlian/ program studi. Oleh karena itu seorang kepala kompetensi keahlian dituntut agar memiliki produktivitas yang tinggi dalam menjalankan tugas pokok dan fungsi mengelola kompetensi keahlian.

Namun demikian produktivitas kepala kompetensi keahlian di SMK DKI Jakarta kondisinya masih belum optimal. Beberapa hal yang mengindikasikan belum optimalnya produktivitas kepala kompetensi keahlian dapat dilihat dari data angka putus sekolah di SMK DKI Jakarta masih tinggi. Tahun 2008, dari total 377.198 siswa SMA dan SMK yang putus sekolah untuk siswa SMK sebanyak 3.188 siswa atau 1,65 persen,

\footnotetext{
* Guru Sekolah Menengah Kejuruan Negeri 35 Jakarta
} 
angka putus sekolah untuk SMA/MA/ SMK tahun 2011 sebanyak 3.085 iswa, tingkat keterserapan lulusan SMK di dunia kerja juga masih belum optimal. Belum optimalnya produktivitas kepala kompetensi keahlian juga dapat dilihat dari segi pelaksanaan tugas manajerial kompetensi keahlian antara lain struktur organisasi dan uraian tugas kepala kompetensi keahlian belum dibakukan dan dilaksanakan secara maksimal, penyusunan program, koordinasi dan evaluasi masih bersifat sebagai kelengkapan administratif yang disusun sendiri oleh kepala kompetensi keahlian. Belum adanya unit produksi atau belum berfungsinya secara optimal baik kuantitas, kualitas maupun relevansi keberadaan unit produksi (bussines center) di tiap kompetensi keahlian.

Belum optimalnya produktivitas kepala kompetensi keahlian juga dapat dilihat dari hasil akreditasi kompetensi keahlian tahun 2009 dan tahun 2010 dari 30 SMK Negeri yang mencakup 90 kompetensi keahlian, setelah dipersentasi diperoleh angka $15,55 \%$ atau 14 kompetensi keahlian hanya mendapat nilai $\mathrm{B}$, dan 23,33\% atau 21 kompetensi keahlian mendapat nilai A kurus dengan nilai 86 s.d 89 . Beberapa peraturan yang ada menunjukkan bentuk perhatian terhadap kepala kompetensi keahlian antara lain: 1) kepala kompetensi keahlian mendapat delegasi dari kepala sekolah untuk merencanakan, melaksanakan, mengevaluasi program kerja di tingkat kompetensi keahlian termasuk anggaran biaya, 2) akreditasi SMK dilaksanakan pada tingkat kompetensi keahlian, 3) salah satu persyaratan untuk menjadi calon kepala SMK minimal pernah menjadi kepala kompetensi keahlian.

Posisi strategis kompetensi keahlian dan kepala kompetensi keahlian tersebut perlu dimaksimalkan fungsi dan tugasnya. Produktivitas kepala kompetensi keahlian yang baik akan meningkatkan kualitas pendidikan SMK. Berdasarkan uraian di atas maka perlu dilaksanakan penelitian tentang produktivitas kepala kompetensi keahlian berkaitan dengan kemampuan manajerial dan pengawasan oleh kepala sekolah.

\section{Produktivitas}

Pengertian produktivitas menurut Newstrom (2002:431), "productivity is a measure of how efficient a person or work activity is; it is determined by comparing (a) the value of the output result with (b) the cost of the input resource". Produktivitas adalah ukuran seberapa efisien suatu kegiatan pribadi atau pekerjaan yang ditentukan dengan membandingkan (a) nilai hasil output dengan (b) biaya sumber daya input. Mosley (2005: 411-412) mengartikan, "productivity is measure that compares outputs to inputs". Produktivitas adalah ukuran yang membandingkan pengeluaran dan pemasukan. Hal ini dapat dijadikan ukuran seberapa efisien kinerja sebuah sistem. Gaspersz mengutip pendapat Mali (1998:18) menyatakan bahwa produktivitas tidak sama dengan produksi, tetapi produksi, performansi kualitas, hasil-hasil, merupakan komponen dari usaha produktivitas. Mengacu pendapat dari Mali tersebut Gaspersz menyimpulkan pengertian produktivitas adalah merupakan kombinasi dari efektivitas dan efisiensi.

Pengertian produktivitas dari beberapa ahli di atas menunjukkan adanya kesamaan pandangan. Pertama bahwa produktivitas dimensinya mencakup efektivitas dan efisiensi penggunaan sumber daya untuk mencapai tujuan. Kedua produktivitas adalah ukuran pengeluaran relatif barang dan jasa terhadap pemasukan tenaga kerja, modal, dan peralatan atau perbandingan antara output dan input. 
Gaspersz (1998:24-25) mengemukakan beberapa manfaat pengukuran produktivitas dalam suatu organisasi/ perusahaan, antara lain:

a. Perusahaan dapat menilai efisiensi konversi sumber dayanya, agar dapat meningkatkan produktivitas melalui efisiensi penggunaaan sumber-sumber daya itu.

b. Tujuan ekonomis dan non ekonomis dari perusahaan dapat diorganisasikan kembali dengan cara memberikan prioritas tertentu yang dipandang dari sudut produktivitas.

c. Strategi untuk meningkatkan produktivitas perusahaan dapat ditetapkan berdasarkan tingkat kesenjangan produktivitas (productivity gap) yang ada di antara tingkat produktivitas yang direncanakan (produktivitas ekspektasi) dan produktivitas yang diukur (produktivitas aktual).

d. Pengukuran produktivitas perusahaan akan menciptakan tindakantindakan kompetitif berupa upaya-upaya peningkatan produktivitas terus menerus (continuous productivity improvement).

e. Pengukuran produktivitas terus menerus akan memberikan informasi yang bermanfaat untuk menentukan dan mengevaluasi kecenderungan perkembangan produktivitas perusahaan dari waktu ke waktu.

f. Pengukuran produktivitas akan memberikan motivasi kepada orang-orang untuk secara terus-menerus melakukan perbaikan dan juga akan meningkatkan kepuasan kerja.

Berdasarkan uraian dari para ahli di atas dapat disintesiskan produktivitas adalah efektivitas dan efisiensi seseorang dalam melaksanakan tugas untuk mengelola organisasi. Indikator dari produktivitas adalah a. efektifvitas meliputi: 1) terlaksananya tugastugas pokok yang telah ditetapkan; 2) pencapaian unjuk kerja secara maksimal; 3) ketepatan waktu penyelesaian; 4) pencapaian tujuan yang telah ditetapkan; dan 5) dapat menghasilkan barang atau jasa yang dihargai oleh pelangan, $b$. efisiensi meliputi: 1) penggunaan sumber daya berupa bahan baku; uang dan manusia serta waktu secara minimal tetapi dapat mencapai hasil yang maksimal; 2) dapat melaksanakan banyak proses atau kegiatan pada waktu yang relatif singkat.

\section{Kemampuan Manajerial}

Sutermaster (1963:8) menjelaskan arti kemampuan, "ability is deemed to result from knowledge and skill". Kemampuan adalah hasil dari pengetahuan dan ketrampilan. Berkaitan dengan penilaian kemampuan yang dimiliki seseorang, Bloom dalam bidang pendidikan mengelompokkan tujuan pendidikan menjadi tiga ranah (domain). Ketiga ranah tersebut adalah ranah kognitif (cognitive domain), ranah sikap (affective domain), dan ranah keterampilan (psychomotor domain). Pada tiga ranah ini yang dijadikan sasaran untuk melakukan penilaian kemampuan dari proses belajar seseorang. Definisi manajemen menurut Ivancevich (2004:5), "management is the process undertaken by one or more persons to coordinate the activities of other persons to achieve results not attainable by any one person acting alone". Manajemen adalah suatu proses yang dikendalikan oleh satu orang atau lebih untuk mengkoordinasi aktivitas yang terjadi dengan orang lainnya untuk hasil maksimal yang tidak dapat diraih secara sendiri.

Kemampuan manajerial menurut Siagian (2009:1) adalah kemampuan untuk mengelola usaha seperti perencanaan, pengorganisasian, pemberian motivasi, 
pengawasan dan penilaian. Kegiatan manajerial meliputi banyak aspek. Oleh karena itu para ahli manajemen memberikan pendapat yang beragam. Namun demikian aspek utama dan sangat esensial dari kegiatan manajerial menurut Fattah (2008:13) yaitu merencanakan (planning), mengorganisasikan (organizing), memimpin (leading), dan mengendalikan (controlling).

Berdasarkan pengertian, fungsi-fungsi manajemen dan uraian manajemen dari beberapa ahli di atas maka dapat disintesiskan yang dimaksud dengan kemampuan manajerial adalah kemampuan kognitif seseorang pada aspek mengetahui, memahami dan mengaplikasikan tugas mengelola organisasi yang meliputi kegiatan merencanakan, mengorganisasikan, memimpin dan mengawasi organisasi agar tercapai tujuan organisasi.

\section{Pengawasan}

Pengawasan merupakan salah satu fungsi dari manajemen. Mosley (2005:390) mendifinisikan pengawasan adalah:Controlling is defined as the management function that involves comparing actual performance with planned performance and taking corrective action, if needed, to ensure that objectives are achieved. Pengawasan didefinisikan sebagai fungsi manajemen yang melibatkan perbandingan antara nilai kinerja yang ada dengan nilai kinerja yang direncanakan sebelumnya dan jika diperlukan dilanjutkan dengan mengambil tindakan perbaikan untuk memastikan tujuan yang akan dicapai. Definisi Pengawasan menurut Robbins dan Coulter (2012:486) adalah: Controlling, It's the process of monitoring, comparing, and correcting work performance. All managers should control even if their units are performing as planned because they can't really know that unless they've evaluated what activities have been done and compared actual performance against the desired standard.

Pengawasan adalah proses memantau, membandingkan, dan mengoreksi hasil kerja. Semua manajer harus mengawasi, walaupun satuan atau unit yang dipimpinnya berjalan sebagaimana yang telah direncanakan. Para manajer tidak dapat mengetahui dengan pasti apabila pekerjaan para karyawan tidak dievaluasi apa yang telah dikerjakan dan kemudian membandingkan hasil kerja yang telah dicapai dengan standar kerja yang diinginkan. Agar pengawasan mencapai sasaran, seorang manajer perlu melakukan pengawasan secara efektif. Pengawasan secara efektif menurut Daft (2010:378): To effectively control an organization, managers need to decide what information is essential, how the will obtain that information, and how they can and should respond to it. Having the correc data is essential. Managers decide which standards, measurements, and metrics are needed to effectively monitor and control the organization and set up systems for obtaining that in formation.

Untuk mengontrol suatu organisasi secara efektif, manajer perlu memutuskan informasi apa yang penting, bagaimana akan mendapatkan informasi itu, dan bagaimana mereka dapat dan harus menanggapinya. Memiliki data yang benar adalah hal yang penting. Manajer menentukan standar, pengukuran, dan metrik yang diperlukan untuk secara efektif memantau dan mengendalikan organisasi dan membuat sistem untuk memperoleh informasi tersebut.

Dari berbagai uraian pengawasan oleh para ahli maka dapat disintesiskan bahwa pengawasan adalah upaya sistematik yang dilakukan oleh pimpinan untuk memantau \& mengarahkan tugas bawahan, memastikan arah pencapaian tujuan, dan membuat koreksi sesuai dengan rencana yang telah ditetapkan. Indikator-indikator dari pengawasan meliputi menentukan standar kinerja, 
mengukur kinerja, membandingkan kinerja dengan standar, dan melakukan tindakan perbaikan.

\section{METODE}

Penelitian ini dilaksanakan di SMK Negeri Provinsi DKI Jakarta. Proses penelitian diselesaikan dalam waktu 5 (lima bulan). Penelitian ini menggunakan pendekatan kuantitatif, metode survei dan teknik korelasional. Populasi terjangkau adalah kepala kompetensi keahlian yang berada di 62 SMK Negeri provinsi DKI Jakarta. Jumlah Kepala Kompetensi keahlian $=227$ orang. Sampel yang digunakan adalah 145 responden. Teknik pengumpulan data yang digunakan pada penelitian ini menggunakan instrumen berbentuk angket. Data dianalisis secara deskriptif dan inferensial

\section{HASIL PENELITIAN DAN PEMBAHASAN}

Berdasarkan hasil pengujian hipotesis terbukti bahwa terdapat hubungan positif antara kemampuan manajerial dan pengawasan dengan produktivitas. Pembahasan hasil penelitian secara lebih mendalam dikemukakan pada uraian berikut:

\section{Hubungan antara Kemampuan Manajerial dengan Prod uktivitas.}

Hasil pengujian hipotesis pertama dapat disimpulkan bahwa terdapat hubungan positif antara kemampuan manajerial dengan produktivitas. Kesimpulan tersebut menunjukkan bahwa semakin tinggi kemampuan manajerial, akan semakin tinggi pula produktivitas. Kuadrat koefisien korelasi antara kedua variabel $\left(\mathrm{r}^{2}\right.$ y1) sebesar 0,1858 dapat diinterpretasikan bahwa bila tidak dilakukan kontrol terhadap pengawasan, maka $19 \%$ proporsi varians produktivitas dapat dijelaskan oleh tingkat kemampuan manajerial. Sedangkan dari bentuk hubungan antara kemampuan manajerial dengan produktivitas ditunjukkan oleh persamaan garis regresi $\hat{Y}=$ $88,05+0,98 \times 1$. Persamaan garis regresi tersebut menunjukkan kebermaknaannya yang berarti pada taraf signifikansi 0,05. Persamaan garis tersebut dapat diinterpretasikan bahwa perubahan satu unit skor produktivitas akan diikuti oleh perubahan skor kemampuan manajerial sebesar 0,98 unit pada arah yang sama dengan konstanta (intercept) sebesar 88,05.

Korelasi antara kemampuan manajerial dengan produktivitas menunjukkan kebermaknanya, baik melalui korelasi product moment maupun korelasi parsial. Hasil analisis ini memberikan petunjuk bahwa kemampuan manajerial merupakan salah satu faktor utama yang berkonstribusi terhadap produktivitas. Dari hasil itu pula dapat diinterpretasikan bahwa peningkatan kemampuan manajerial akan memberikan konstribusi yang berarti terhadap produktivitas. Hal ini sesuai dengan pendapat Mosley (2005:415) "a major force in determining productivity is management". Sebuah kekuatan utama dalam menentukan produktivitas adalah manajemen. Dalam hal ini Siagian juga berpendapat bahwa karena manajemen merupakan motor penggerak dalam kehidupan organisasi, faktor kemampuan manajerial merupakan faktor yang paling dominan menentukan apakah organisasi mampu bergerak secara efisien, efektif, dan produktif untuk mencapai tujuan dan sasaran yang telah ditetapkan sebelumnya.Hasil pengujian hipotesis ini juga didukung hasil penelitian tentang, "Making The Most Of What You Have: Managerial Ability As A Source OF Resource Value Creation" yang dilakukan oleh Holcomb, Holmes JR, Connelly. Hasil dari penelitian, "results indicate that relationship 
between managerial ability and resource productivity for offensive and defensive combinations is positive and significant". ${ }^{4}$ Hasil penelitian menunjukkan bahwa hubungan antara kemampuan manajerial dan produktivitas sumber daya untuk kombinasi ofensif dan defensif adalah positif dan signifikan.

\section{Hubungan antara Pengawasan dengan Produktivitas.}

Hasil pengujian hipotesis kedua dapat disimpulkan bahwa terdapat hubungan antara pengawasan dengan produktivitas. Kesimpulan tersebut menunjukkan bahwa semakin tinggi pengawasan, akan semaki $\mathrm{n}$ tinggi pula produktivitas. Kuadrat koefisien korelasi antara kedua variabel $\left(\mathrm{r}^{2}\right.$ y2) sebesar 0,3648 dapat diinterpretasikan bahwa bila tidak dilakukan kontrol terhadap kemampuan manajerial, maka $36 \%$ proporsi varians produktivitas dapat dijelaskan oleh tingkat pengawasan. Sedangkan dari bentuk hubungan antara pengawasan dengan produktivitas ditunjukkan oleh persamaan garis regresi $\hat{Y}=61,71+0,45 X 2$. Dari persamaan garis regresi tersebut menunjukkan kebermaknaannya yang berarti pada taraf signifikansi 0,05. Persamaan garis regresi tersebut dapat diinterpretasikan bahwa perubahan satu unit skor produktivitas akan diikuti oleh perubahan skor pengawasan sebesar 0,45 unit pada arah yang sama dengan konstanta (intercept) sebesar 61,71.

Korelasi antara pengawasan dengan produktivitas menunjukkan kebermaknannya, baik melalui korelasi product moment maupun korelasi parsial. Hasil analisis ini memberikan petunjuk bahwa pengawasan merupakan salah satu faktor utama yang berkonstribusi terhadap produktivitas. Dari hasil itu pula dapat diinterpretasikan bahwa peningkatan pengawasan akan memberikan konstribusi yang berarti terhadap produktivitas. Hal ini sesuai dengan pendapat Sharp, “.... When supervisors discharge their duties effectively, productivity rises and employees enjoy greater job satisfaction". Ketika pengawas melaksanakan tugasnya secara efektif, produktivitas meningkat dan karyawan menikmati kepuasan kerja yang lebih besar.

Salah satu tugas seorang pimpinan adalah tugas pengawasan kepada stafnya. Pengawasan dalam hal ini dilaksanakan melalui empat langkah pengawasan. Menurut Daft (2010:381-382) keempat langkah tersebut adalah, "...: Establish standars, measure performance, compare performance to standards, and make corrections as necessary." Dengan empat langkah pengawasan: membangun standar, mengukur kinerja, membandingkan kinerja dengan standar, dan membuat koreksi yang dibutuhkan maka pengawasan dapat meningkatkan produktivitas. Secara implisit Siagian juga berpendapat bahwa pengawasan merupakan alat yang ampuh untuk meningkatkan produktivitas.

Hasil pada tabel menunjukkan bahwa sistem penilaian kinerja $(\mathrm{r}=0,5549, \mathrm{p}<$ $0,05)$ dan sistem gaji $(r=0,5995, \mathrm{p}<0,05)$ secara signifikan berhubungan dengan produktivitas perusahaan. Penelitian dilakukan di beberapa perusahaan yang berada di Indonesia. Ini berarti bahwa dengan menerapkan sistem penilaian kinerja yang baik dan sistem gaji akan membawa perubahan yang signifikan pada produktivitas perusahaan. Penelitian Prasetya dan Kato tersebut menunjukkan bahwa penilaian kinerja yang merupakan salah satu langkah dalam pengawasan ada hubungan yang signifikan dengan produktivitas.

\section{Hubungan antara kemampuan Manajerial dan Pengawasan secara Bersama-sama dengan Produktivitas.}


Hasil pengujian hipotesis ketiga dapat disimpulkan bahwa kemampuan manajerial dan pengawasan secara bersama-sama mempunyai hubungan positif dengan produktivitas. Koefisien korelasi ganda antara kedua variabel bebas dengan variabel terikat (Ry.12) sebesar 0,656. Dari koefisien korelasi tersebut, dapat dihitung koefisien determinasi $\left(\mathrm{R}^{2}\right.$ y.12) sebesar 0,4297 berarti bahwa $43 \%$ proporsi varians produktivitas dapat dijelaskan secara bersama-sama oleh kemampuan manajerial serta pengawasan.

Kesimpulan hipotesis ini sesuai dengan pendapat Mosley (2005:416) mengenai beberapa kelompok yang mempengaruhi produktivitas meliputi, "management, government, individual workers and unions". Manajemen, pemerintah, karyawan dan serikat pekerja merupakan empat komponen yang mempengaruhi produktivitas. Manajemen di dalamnya mencakup pengawasan. Faktor karyawan akan sangat ditentukan oleh kemampuan yang dimiliki oleh karyawan tersebut. Berdasar pendapat Mosley yang mengelompokkan manajemen dan karyawan sebagai bagian yang mempengaruhi produktivitas maka dengan demikian pengawasan dan kemampuan yang merupakan komponen dari manajemen dan karyawan ada hubungan dengan produktivitas.

Sejalan dengan kesimpulan hipotesis, Sinungan (2009:56) juga mengemukakan faktor-faktor produktivitas dari unsur manusia diantaranya adalah kemampuan, sikap sedangkan dari unsur metode/proses diantaranya perencanaan dan pengawasan produksi.Dengan demikian hasil pengujian hipotesis didukung oleh teori-teori bahwa terdapat hubungan antara kemampuan manajerial dan pengawasan secara bersama-sama dengan produktivitas.

\section{PENUTUP}

\section{Kesimpulan.}

Berdasarkan hasil pengujian hipotesis dan pembahasan yang telah diuraikan pada Bab IV, maka dapat diambil beberapa kesimpulan sebagai berikut: Pertama, terdapat hubungan positif antara kemampuan manajerial dengan produktivitas kepala kompetensi keahlian di SMK Negeri DKI Jakarta, Kedua, terdapat hubungan positif antara pengawasan kepala sekolah dengan produktivitas kepala kompetensi keahlian di SMK Negeri DKI Jakarta, Ketiga, terdapat hubungan positif antara kemampuan manajerial dan pengawasan secara bersama-sama dengan produktivitas kepala kompetensi keahlian di SMK Negeri DKI Jakarta

\section{Implikasi.}

\section{Upaya meningkatkan kemampuan manajerial}

Upaya-upaya untuk meningkatkan kemampuan manajerial adalah melalui workshop, upgradingtentang materi manajemen umum maupun manajemen khusus pada kompetensi keahlian. Upaya melalui pola rekrutmen kepala kompetensi keahlian sesuai dengan persyaratan yang telah ditentukan. Selain itu juga perlu melengkapi sarana prasarana kepala kompetensi keahlian sesuai standart misalnya adanya ruangan kepala kompetensi keahlian . Perlu struktur organisasi kompetensi keahlian yang baku serta uraian tugas yang jelas. Kepala sekolah memberikan peran yang proporsional kepada kepala kompetensi keahlian untuk mengelola sekolah di tingkat kompetensi keahlian. Kepala sekolah memberdayakan sekaligus mengawasi tugas manajerial kepala kompetensi keahlian dalam hal penyusunan program, koordinasi, pelaksanaan dan evaluasi program kompetensi keahlian 
sehingga tugas-tugas manajerial kepala kompetensi keahlian dapat dilaksanakan secara maksimal.

\section{Upaya meningkatkan pengawasan.}

Beberapa upayauntuk meningkatkan pengawasan terhadap kepala kompetensi keahlian.Kepala sekolah menetapkan standar kompetensi keahlian yang telah disusun oleh kepala kompetensi keahlian bersama guru kejuruan pada masing-masing kompetensi keahlian. Kepala sekolah selain mengadakan supervisi akademik kepada guru juga mengadakan supervisi manajerialkepada kepala kompetensi keahlian. Audit internal maupun audit eksternal model sistem manajemen mutu sesuai ISO perlu dilakukan oleh kepala sekolah terhadap kepala kompetensi keahlian. Kepala sekolah membuat tagihan laporan pelaksanaan dan laporan keuangan kegiatan kompetensi keahlian secara berkala. Agar pengawasan terselenggara dengan efektif kepala sekolah dapat melakukan strategi melalui berbagai instrumen untuk melakukan pengawasan antara lain adalah 1) pengawasan dengan menggunakan standar hasil yang direncanakan untuk dicapai,2) anggaran sebagai instrumen pengawasan, 3) data statistik sebagai instrumen pengawasan, 4) laporan sebagai instrumen pengawasan, 5) Observasi langsung sebagai instrumen pengawasan.

\section{Saran}

Berdasarkan kesimpulan dan implikasi penelitian ada beberapa saran dalam rangka meningkatkan produktivitas Kepala Kompetensi Keahlian sebagai berikut:

Pertama, untuk meningkatkan kemampuan manajerial kepala kompetensi keahlian hendaknya PSMK mengaktifkan kembali program pelatihan pengelolaan bengkel maupun manajemen umum. Dinas Pendidikan Propinsi DKI Jakarta melaksanakan workshop/ up grading tentang manajemen kepada kepala kompetensi keahlian di SMK DKI Jakarta. Sudin Dikmen pada setiap Kota Administratif melaksanakan program pembinaan kepada kepala kompetensi keahlian.

Kedua, kepala sekolah membuat program peningkatkan manajemen sekolah menengah kejuruan (SMK) di tingkat kompetensi keahlian.Ketiga, monitoring dan evaluasi (ME) yang diadakan tiap tahun sekali oleh pengawas hendaknya juga dilakukan terhadap kepala kompetensi keahlian dengan format monitoring evaluasi (ME) yang telah dibakukan. 


\section{DAFTAR RUJUKAN}

Brinkerhoff, Robert O., Dressler, Dennis E. Productivity Measurement A Guide for managers and Evaluators. California: Sage Publications, Inc., 1990.

Cascio, Wayne F. Managing Human Resources. Productivity, Quality of Work Life, Profits. New York: By The McGraw-Hill, 2003.

Colquitt, Jason A. et.al., Organizational Behavior. Improving Performance and Commitment in the Workplace. New York: Mc Graw Hill Companyes, Inc., 2009,

Daft, Richard L. New Era of Management . Canada: by Nelson Education, Ltd., 2010.

Danim, Sudarwan, dkk. Manajemen dan kepemimpinan Transformasional Kekepalasekolahan. Jakarta: PT. Rineka Cipta, 2009.

Dessler, Gary. Management. Leading People and Organizations in the 21st Century. New Jersey: Prentice Hall, Inc., 2001.

Fattah, Nanang. Landasan Manajemen Pendidikan. Bandung: PT. Remaja Rosdakarya, 2008.

Gillmore,John V.The Productive Personality. California:Albion Publishing Company, Inc., 1974.

Gaspersz, Vincent. Manajemen Produktivitas Total. Strategi Peningkatan Produktivitas Bisnis Global. Jakarta: PT. Gramedia Pustaka utama, 1998.

Holcomb, R. Michael Holmes JR., and Brian L. Connelly, "Making The Most Of What You Have: Managerial Ability As A Source Of Resource Value Creation". Strategic Management Journal, 30: 457-485 (2009). http:/ / cortoleo.free.fr/Ms/smj\%2009\%20RBV\% 20Sport.pdf (diakses 12 April 2012).

Ivancevich, John M. etal. Management Prinsiples and Functions. Krishan Nagar, Delhi: A.I.T.B.S. Publishers \& Distributors (Regd.), 2004.

Mosley, Donald C., Megginson, Leon C., Pietri, Paul H. Supervisory management. The Art of Inspiring, empowering, and developing People. South-Western: by south-Western, part of the Thomson Corporation, 2005.

Mulyasa, E. Manajemen Berbasis Sekolah. Bandung: PT. Remaja Rosdakarya, 2007.

Riduwan (ed.). Manajemen Pendidikan. Bandung: PT. Alfabeta, 2010.

Rivai, Veithzal, Murni, Sylviana. Education Management. Analisis Teori dan Praktik. Jakarta: PT. Raja Grafindo Persada, 2009.

Robbins, Stephen P., Coulter, Mary. Management. New Jersey: Prentice Hall, 2012

Robbins, Stephen P., Judge, Timothy A. Organizational Behavior. New Jersey: Pearson Education, Inc., 2007.

Schermerhorn, John R. Introduction to management. Asia: John Wiley \& Son (Asia) Pte td, 2010.

Sagala, Syaiful. Kemampuan Pro fesional Guru dan Tenaga Kependidikan. Bandung: Penerbit Alfabeta, 2011 
Sedarmayanti. Sumber Daya Manusia dan Produktivitas Kerja. Bandung: CV. Mandar Maju, 2009.

Sinungan, Muchdarsyah. Produktivitas Apa dan Bagaimana. Jakarta: PT. Bumi Aksara, 2009.

Sutermeister, Robert A. People and Productivity. United States of Amerika: McGraw-Hill Book Company, 1963

Sudjana. Metoda Statistika. Bandung: Penerbit Tarsito, 2005.

Siagian, Sondang P. Kiat Meningkatkan Produktivitas Kerja. Jakarta: PT. Rineka Cipta, 2009.

Siagian, Sondang P. Fungsi-Fungsi Manajerial. Jakarta: PT. Bumi Aksara, 2007.

Sirait, Justin T. Memahami Aspek-Aspek Pengelolaan Sumber daya manusia dalam Organisasi.Jakarta: PT. Grasindo, 2007.

Thomas. J. Alan. The Productive School,: A system analysis approach to Educational Administration, Canada: John wiley \& Sons., Inc., 1982.

Terry, George R., Rue, Leslie W. Dasar-dasar Manajemen. Jakarta: PT. Bumi Aksara, 2005.

Wahyudi. Kepemimpinan Kepala Sekolah. Dalam Organisasi Pembelajar (learning Organization). Bandung: CV Alfabeta, 2009. 